\title{
EcoSmart Energy and Health Care Promotion in Senior Tourism
}

\author{
Amila Pilav-Velic, Nedim Suta, Anes Hrnjic \\ University of Sarajevo, Bosnia and Herzegovina
}

\section{Abstract}

Recent studies show that seniors will soon become one of the major prospective segments in hospitality and travel industry. Given that population aged 65+ is usually retired with pensions, they have leisure time for travelling at any time of the year. They are also the most demanding expecting services excellence and high-level security while at the same time $63 \%$ of seniors aged $65-74$ reported some sort of chronic illness. Hence, energy-efficient and health-focused facilities can be a significant potential for tourism development in Sarajevo region, which is a popular destination considering its unique nature, rich gastronomic, cultural and historical heritage. However, currently there is no market segmentation tailored to specific needs of senior tourists and research aims to explore opportunities and potential for this type of services with the objective of introducing accommodation facilities for elderly based on eco-smart solutions with highlighted focus on well-being and health. Setting of still water machines and installation of renewable energy system for electricity, ventilation and heat can have various positive effects increasing security, providing more healthy conditions, influencing life expectancy and counteracting the aging. Thus, research goal is creating feasibility study on eco-smart and healthfocused facility for senior tourists in Sarajevo region using strategic management tools as a methodology instruments, including application of PEST concept, determining industry development phase as well as evaluating its structure, attractiveness and profitability via five forces of Porter model. Recommendations for future studies as well as practical implications for appropriate business actions are given in the conclusion relating to senior tourism development in Sarajevo region.

Keywords: senior tourism, eco-smart energy, health care, sustainable development JEL classification: L83, Q57, O13

\section{Introduction}

Aging of population in majority of nations along with other changes such as sociodemographics, health status and travel behavioral patterns is one of primary reasons for the development of target group that can be referred to as the senior segment (Patterson, 2006; Schroder et al., 2007; Nimrod et al., 2010). Abovementioned sociodemographic trends influencing traveling behavior patterns of elderly population are significantly determined by economic factors and social conditions such as the slowing of population and household growth and an increasing segmentation of travel markets implicating the shift from production market to market research and the promotion at smaller target groups, including senior population, such as regional and local marketing (Nedelea et al., 2011). The importance of current and future mature population is explained in several works highlighting the desirability of not limiting tourist offer to the specifications of the elderly consumers today, but also exploring the potential buying patterns (Tongren, 1988; Littrell et al., 2013).

Nowadays $63 \%$ of seniors aged $65-74$ reported some sort of chronic illness and studies found that activation intervention via traveling is a potentially promising 
approach to changing senior population lifestyle that can to some degree improve chronic disease outcomes and general health status (Frosch et al., 2010). Taking in consideration what was above mentioned, energy-efficient and health-focused facilities can be a significant potential for tourism development in Sarajevo region, which is a popular destination considering its unique nature, rich gastronomic, cultural and historical heritage. Bosnia and Herzegovina with its capital was always open for tourists from foreign countries which is shown in the tourist's flows data, i.e. 46,261 tourist visits in 2009 from Western Europe or 50,838 tourists from neighboring Croatia in the period 2002-2012 who recorded 93,601 overnight stays, which presents almost $14 \%$ to overall overnight stays for the observed period (Ozlen et al., 2013).

However, currently there is no market segmentation tailored to specific needs of senior tourists in Sarajevo. Thus, research goal is creating feasibility study on ecosmart and health-focused facility for senior tourists in Sarajevo region using strategic management tools. Statistics implicate that the segment of senior population will increase the overall volume of revenue generated in tourism sector the most compared to other groups since these elderly adults allow tourist demand to shift away from peak periods of the year because they are usually retired with pensions and have leisure time for travelling at any time of the year (Alén et al., 2012). The paper structure includes a literature review presented in the introduction following detailed explanation of methodology, presentation of analysis results based on the collected secondary data and, in the end, research results are discussed in terms of practical implications, limitations and recommendations for future studies followed by conclusions and list of references used.

\section{Methodology}

Methodology of the paper is based on several descriptive analytical methods, namely PEST concept analysis incorporating the numeric evaluation of factor influence, industry sector analysis including development phase through the life cycle prism and the Porter model aimed at a long-term structural analysis of the particular industry, its attractiveness and profitability, which are further explained in detail. PEST concept is commonly used analytical approach in consideration of external environment examining political, economic, social and technological influence and describing a macro factors framework which is an important component of the strategic management environmental scanning (Gupta, 2013). Industry sector analysis consists of the determination of specific industry for which the business is relevant to and its phase of adjustment as well as the Porter model of evaluation of attractiveness and profitability of the segment. Porter model consists of five forces, specifically threat of new entries, negotiation of power of suppliers as well as buyers, substitution possibility and competition analysis is considered as a crucial framework of strategic planning for the business (Jaradat et al., 2013). Application of Porter model is a very helpful business tool in evaluating the company's environment and deepening business understanding of its core competitive position that extends beyond the current competition threat. Since there is no tourism facility for elderly population in Sarajevo region that is based on energy-efficient and wellness-oriented solutions, the initial development step should be related to in-detail environmental analysis in terms of feasibility of creating this particular tourist offer.

Abovementioned analytical methods were selected in order to fulfill the main objective of the research related to exploration of trends in tourism industry that are specific for Sarajevo region and analysis of the possibilities of creating a novel tourist offer in the particular region specially customized to senior population and their customer preferences in regard to socio-demographic perspectives of international 
travel and tourism industry. In order to apply methodological instruments described above, secondary data was collected from relevant sources, including official statistical reports from local governmental bodies such as Statistics Federal Agency or Sarajevo Canton Tourist Board as well as international reports such as reports created by the World Economic Forum or European Parliament. In order to determine the feasibility and potential of above explained tourist offer, strategic management tools for external business analysis were applied in accordance to data collected from the secondary sources. Since the nature of analyzed business includes a comprehensive use of eco-smart and health-supporting solutions and technology, concepts of sustainability, efficacy and health are discussed. At the end of the paper, practical implications for future actions are highlighted and explained.

\section{Results}

The following macro environmental influences that are specific for the potential ecosmart and health-oriented business operating in Sarajevo region were identified (shown below in Table 1):

Table 1

Identification of External Environmental Factors - Macro Environment

\begin{tabular}{|c|c|}
\hline Political and Legal Factors & Economic Factors: \\
\hline - Political climate/government stability & - Gross Domestic Product trends \\
- European Union integration process & - Inflation rate stability \\
- Tax administration policy-VAT & - Interest rate fluctuations \\
- Government spending for tourism & - Expenditures \\
- Present/future laws in tourism sector & - Unemployment rate \\
\hline Social and Cultural Factors & Technological Factors \\
\hline - Changes in lifestyles of tourists & - Use of Information technology \\
- Habit and behavior changes & in tourism industry such as computer \\
- Changes in the use of disposable & reservation systems (CRS) \\
income & - Technological advances enabling the \\
- Attitudes toward the & effient use of energy and \\
job responsibilities and leisure time & sustainable development of tourism \\
\hline
\end{tabular}

Source: Authors

After identifying relevant external factors, the evaluation of their influence is performed with regard to two basic aspects: influence evaluation of identified factors by grading a threat from -5 to 0 , and an opportunity from 0 to +5 and importance evaluation of business strategic factors by grading them from 0 to +10 . The evaluation of identified factors for tourist market regarding company's request is shown in below (Table 2). 
Table 2

Factor Influence and Importance Evaluation

\begin{tabular}{|c|c|c|c|}
\hline Environment & Factor influence & Factor importance & $\begin{array}{c}\text { Opportunity (+); } \\
\text { threat (-) }\end{array}$ \\
\hline Political/Legal (P) & -3 & 8 & -24 \\
\hline Economic (E) & 3 & 7 & 21 \\
\hline Social/Cultural (S) & 2 & 6 & 12 \\
\hline Technology (T) & 2 & 4 & 8 \\
\hline Total & - & - & 17 \\
\hline
\end{tabular}

Source: Authors

Political and legal environment: Current political situation is relatively unstable resulting in insufficient number of foreign tourists. However, according to the official statistics the country's tourism revenue in 2013 reached an all-time record. Correspondingly, there is a tendency towards the stabilization of political scene as well as the intention of governmental institutions to create programs that will positively influence the image of the country at the international level. When it comes to the tourism in Sarajevo region, Federal Law on Tourism is the most relevant document regulating the tourism industry, types of services offered, conditions and models of performing these activities, including entities which can be engaged.

Economic environment: According to the National Agency for Statistics (Kozic et al., 2014), GDP growth in the last year was $0.6 \%$ while GDP per capita was 6,862 KM. Even though, GDP growth remains on a declining trend in most of the European Union countries, we can expect that discretionary income will continue to go up at least when it comes to the foreign senior guests and that will have a direct repercussion on increasing the spending on tourism services. Senior population has low fixed living costs, $82 \%$ of all seniors own their home outright and most of them own cars. Hence, the senior market is one of the fastest growing areas of tourism and this trend is evident in Bosnia and Herzegovina too, but mostly when it comes to foreign senior tourists.

Social and cultural environment: Sarajevo is the capital of Bosnia and Herzegovina and country's administrative, economic, cultural, educational and sport center. For centuries Sarajevo has been the city of multiculturalism where Catholics, Muslims, Jews and Orthodox live together. Sarajevo also has a rich history ranging from the early Neolithic to medieval period, including impressive influences of the Ottomans and Austro-Hungarians on culture and arts. Sarajevo region includes an envious natural heritage such as canyons, Olympic Mountains or thermal springs which are significant for medical senior tourism. National cuisine and festivals such as Jazz Fest, Film Festival, MESS and others should not be neglected in tourism potential analysis.

Technological environment: The use of IT-based solutions in tourism influenced the increase of quality of tourist travel and quality of visitations. More and more tourist destinations are available through detailed tourist information web systems. Unfortunately, in Bosnia and Herzegovina this type of environment, at least in tourism industry, is not sufficiently developed.

From the positive value of threats and opportunities, it is clear that opportunities exceed threats. In order to emphasize all relevant aspects of the particular industry, it is necessary to do Industry Sector Analysis for the potential business. The relevant industry is the hotel industry and tourism. Life cycle prism is shown below (Figure 1). 
Figure 1

Industry Development Phase Representation through Life Cycle Prism

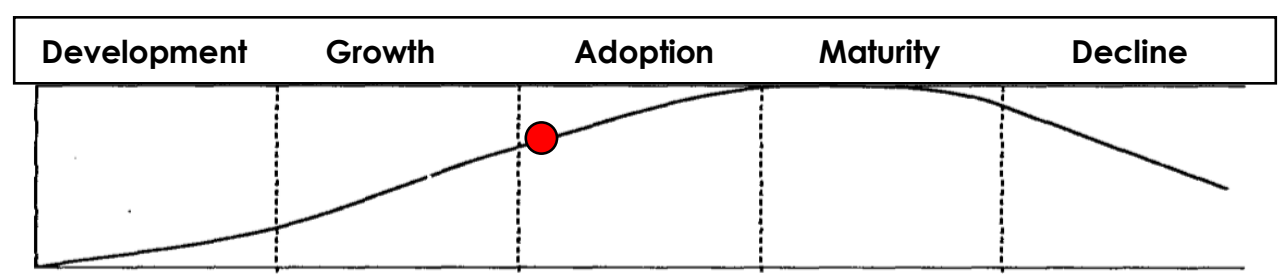

Source: Authors

Generally, the relevant industry is in the beginning phase of adjustment. World Economic Forum publishes the Travel and Tourism Competitiveness Report annually and Bosnia and Herzegovina's Travel and Tourism Competitiveness Index for the year of 2013 was 3.8 which gives the country a rank of 90 out of 140 countries with comparable data (Blanke et al., 2013). Further results present the long-term structural analysis of industry, its attractiveness and profitability using Porter model.

Table 3

Long-term structural analysis of industry using Porter model

\begin{tabular}{|c|c|c|}
\hline $\begin{array}{l}\text { Observed Porter } \\
\text { model force }\end{array}$ & $\begin{array}{l}\text { Results of } \\
\text { analysis }\end{array}$ & Explanation \\
\hline $\begin{array}{l}\text { The threat of } \\
\text { new entry }\end{array}$ & medium & $\begin{array}{l}\text { - Relatively high initial investments } \\
\text { (makes high entry, but also high exit barriers); } \\
\text { - Low brand loyalty and narrow location }\end{array}$ \\
\hline $\begin{array}{c}\text { Negotiation } \\
\text { power of suppliers }\end{array}$ & low & - Large number of potential suppliers \\
\hline $\begin{array}{l}\text { Negotiation } \\
\text { power of buyer }\end{array}$ & high & $\begin{array}{l}\text { - Service replacement costs are very low; } \\
\text { - Tourists are very sensitive consumers } \\
\text { (requiring good quality services) }\end{array}$ \\
\hline $\begin{array}{l}\text { Substitution } \\
\text { possibility }\end{array}$ & low & $\begin{array}{l}\text { No market segmentation or tourist offer } \\
\text { tailored to the specific needs of a particular } \\
\text { group of visitors, including elderly population }\end{array}$ \\
\hline $\begin{array}{c}\text { Competition } \\
\text { degree }\end{array}$ & emphasized & $\begin{array}{l}\text { - There is a substantial competition in tourism } \\
\text { industry, but there are no facilities customized } \\
\text { to senior tourists (explained in the text below) }\end{array}$ \\
\hline $\begin{array}{c}\text { General } \\
\text { conclusion }\end{array}$ & $\begin{array}{l}\text { attractive } \\
\text { industry }\end{array}$ & $\begin{array}{l}\text { There is no single tourism offer based on } \\
\text { energy-efficient and eco-smart facilities } \\
\text { tailored to specific needs of elderly tourists }\end{array}$ \\
\hline
\end{tabular}

Source: Authors

Currently, in Sarajevo region there are 61 registered hotels operating in the tourism industry grouped into categories as follows: 3 five-stars hotels, 11 four-stars hotels, 28 three-stars hotels, 8 two-stars hotels, 3 one-stars hotels and 8 hotels without a category (but most of them are in the process of obtaining categorization). The majority of hotels fall under three-star category and their offer fulfills cost benefit balance of an average consumer in terms of condition and cleansings. However, none of 61 hotels that were evaluated does not have any type of service based on eco-smart and energy-efficient solutions or adapted for elderly guests. 


\section{Discussion}

Environmental influences refer to all physical, biological and chemical factors that have an impact on an individual, i.e. its health and behavior. Therefore, the estimate and control of all environmental factors as well as their contamination and protection, represents an important issue of mankind for decades regardless of the level of societal development and productiveness across the planet. These issues are put in the limelight of science with an emphasis on its current relevance and it is easy to come to conclusion that healthy environment is not abundant directly negatively influencing the living biological system, especially senior citizens (Stankovic, 1995). Directly in reference to these facts, the sustainable development theory attempts to reduce the level of negative influences of biological factors on persons' physical, psychological and social well-being through the harmonization of social, economic and environmental factors (Vasovic et al., 2007).

Given that health is the result of a mechanism of mutual adjustment of human beings and their environment, modern and urban lifestyle represents a direct stress for elderly citizens and their already slow physiological system failing to make an adequate adjustment. For instance, inability of the interior environment to repeatedly establish a necessary balance with the fast changing exterior environment has resulted in a number of diseases emergence of which the most common are circulatory system diseases, locomotor diseases and other neuropsychological, endocrine, metabolic and immune system diseases (Wigle, 2003; Wells et al., 2010). Out of total area of Sarajevo region, $65.43 \%$ is covered with forests $(82.998,88 \mathrm{ha})$, which means a tremendous potential for the development of ecosmart tourism that can meet almost all physiological and social needs of elderly citizens. Human beings' origin is in nature and they have never completely separated from it, so it is expected that third age persons, governed by their instincts, always opt for such locations with high natural potential as their vacation spots.

The latest scientific research in cell physiology has proved that system repair mechanisms can only be initiated in natural conditions. It has also been confirmed that environment can increase or reduce stress. Therefore, stress caused by noise, which is part of a modern lifestyle, accelerates the production of stress proteins in elderly persons that block cells of the immune system causing the feeling of anxiety, depression, high blood pressure and muscle tension, which are starting point for the incidence of the aforementioned diseases. Stress is a big medical problem of the modern society and therefore it is extremely important to offer a stress-free environment during vacations, especially to elderly persons in order to maintain a normal functioning of physiological system with the possibility of activating intracellular reparation systems for the improvement of the overall human well-being, especially of senior population (Kaplan et al., 1989; Evans, 2001).

Apart from forests, Sarajevo holds thermal springs. The most famous one is located in llidza municipality. These thermal springs are sulfuric waters rich with calcium, sodium, potassium and hydrocarbons. Hence, they are used for prevention and treatment of all diseases suffered by elderly persons such as rheumatism, neuralgia, anemia, skin, digestive system and urinary tract diseases. Sulphur, as the main ingredient in these waters, is very important for glucose metabolism. The lack of this chemical element in elderly persons leads to musculoskeletal disorders, obesity and metabolic syndrome. The latest scientific research has proved that one of the causes of Alzheimer's disease is a significant reduction of the amount of sulfur in such patients when compared to healthy persons (Anderson, 2007). However, feasibility study is the initial step in offer creation, which is also the limitation. Hence, future research should evaluate in detail commerce potential of specific tourist services. 


\section{Conclusion}

Tourism represents a quiet dynamic industry which includes unique characteristics that can be observed as an essential segment of national economy in developed countries as well as developing countries such as Bosnia and Herzegovina. Travel industry contains all the phenomena and relationships covering interactions between tourists, suppliers and vendors of tourist services, national and local governmental bodies and host communities in the process of attracting and welcoming tourists at a particular destination (Hadiani et al., 2011). Performances and outcomes of these relationships in tourism industry considerably influence national economy results in the form of employment rate and its impact on economic and social development as well as environmental sustainability including protection of natural resources through creation of energy-efficient solutions. Tourism industry in Bosnia and Herzegovina with its capital in Sarajevo records a positive trend for all crucial indicators of growth in the last decade or so (Bidzan et al., 2015). These trends in tourism/travel industry can be a solid base for initiation of further economic and societal development by creating specific target group and customer segmentation in terms of tourist offer that would be specially tailored to elderly population due to socio-demographic characteristic of future senior citizens.

There is also a substantial space for additional use of its indisputable potential that involves extensive natural resources such as Olympic mountains Bjelasnica, Igman and Jahorina located only half an hour drive from the Sarajevo downtown, long and well-known heritage/tradition, exciting and restless history, favorable geographic location on the crossroads between eastern and western cultures, internationally popular events such as Sarajevo Film Festival, outstanding gastronomic offer at a reasonable price and the status of still unknown tourist destination for the majority of foreign tourists outside European continent. Setting of still water machines and installation of renewable energy system for electricity, ventilation and heat can have various positive effects increasing security, providing more healthy conditions, influencing life expectancy and counteracting the aging in elderly population. These practices can be observed as possible strategies of creating a unique hotel facility in Sarajevo region customized to needs of senior tourists. Strategic management tools have shown that there is business, socio-demographic, biological and psychological (health-related) rational for creating an eco-smart and energy-efficient tourist facility in Sarajevo that could become profitable in a short period of time. However, future research should seek to explore in more detail the commerce potential of senior tourism services in Sarajevo region since feasibility study is just an initial step.

\section{References}

1. Alén, E., Domínguez, T., Losada, N. (2012), "New Opportunities for the Tourism Market: Senior Tourism and Accessible Tourism", available at: http://cdn.intechopen.com/pdfswm/35523.pdf (accessed July $1^{\text {st }}$ 2015).

2. Anderson, J. (2007), "Climate change-induced water stress and its impact on natural and managed ecosystems", Report, European Parliament, IP/A/CLIM/ST/2007.06.

3. Bidzan, A., Gekic, H. (2015), "Regional aspect of tourism development in Bosnia and Herzegovina", International Journal of Innovation and Applied Studies, Vol. 11 No. 4, pp. 886893.

4. Blanke, J., Chiesa, T. (2013), "The travel \& tourism competitiveness report 2013", Geneva: The World Economic Forum.

5. Evans, G.W. (2001), "Environmental stress and health", in Handbook of Health Psychology, edited by A. Baum, T. Revenson, and J. E. Singer, Erlbaum, Mahwah, NJ.

6. Frosch, D.L., Rincon, D., Ochoa, S., Mangione, C.M. (2010), "Activating seniors to improve chronic disease care: results from a pilot intervention study", Journal of the American Geriatrics Society, Vol. 58 No. 8, pp. 1496-503. 
7. Gupta, A. (2013), "Environment \& PEST analysis: An approach to external business environment", International Journal of Modern Social Sciences, Vol. 2 No. 1, pp. 34-43.

8. Hadiani, Z., Ahadnezhad, M., Kazemizad, S. , Ghanbari, H. (2011), "Strategic planning for tourism development by SWOT method (Case study: Shiraz City)", Geography and Environmental Planning Journal, Vol. 47 No. 3, pp. $29-32$.

9. Kaplan, R. \& Kaplan, S. (1989), "The experience of nature: A psychological perspective", New York: Cambridge University Press.

10. Kozic, E. \& Papaz, V. (2014), "First release of Annual Report 2013", Agency for Statistics of the Bosnia and Herzegovina.

11. Littrell, M.A., Paige, R.C., Song, K. (2013), "Senior travelers: Tourism activities and shopping behaviors", Journal of Vacation Marketing, Vol. 1, pp. 348-362.

12. Nedelea, A., State, M. (2011), "The demographic aging and consumer market", ESS, Annals of the University of Oradea, pp. 1008-1012.

13. Nimrod, G., Rotem, A. (2010), "Between relaxation and excitement: activities and benefits gained in retirees' tourism", International Journal of Tourism, Vol. 12, pp. 65-78.

14. Ozlen, M. K., Poturak, M. (2013), "Tourism in Bosnia and Herzegovina", Global Business and Economics Research Journal, Vol. 2 No. 6, pp. 13-25.

15. Patterson, I. (2006), "Growing older: tourism and leisure behavior of older adults", CABI, Oxfordshire, UK; Cambridge, MA.

16. Schroder, A., Widmann, T. (2007), "Demographic change and its impact on the travel industry: oldies - nothing but goldies?" Trends and Issues in Global Tourism", Springer: Berlin and Heidelberg, Germany, pp. 3-17.

17. Stankovic, M.S. (1995), "Pozitivni i negativni uticaji turizma na životnu sredinu" [Positive and Negative Effects of Tourism on the Environment], Glasnik SGD: Beograd, sv. LXXV, 1, pp. 47-48.

18. Tongren, H.N. (1988), "Determinant behavior characteristics of older consumers", The journal of Consumer Affairs, Vol. 22 No. 1, pp. 136-157.

19. Vasovic V. \& Biocanin R. (2007), "Odrzivi razvoj" [Sustainable Development], Ecologica, Naucno drustvo za zastitu.

20. Wells, N.M., Evans, G.W., Yang, Y. (2010), "Environments \& health: Planning decisions as public-health decisions", Journal of Architectural and Planning Research, Vol. 27 No. 2, pp. 124-143.

21. Wigle, D.T. (2003), "Child health and the environment", New York: Oxford University Press.

\section{About the authors}

Amila Pilav-Velić, PhD is Assistant Professor at School of Economics and Business in Sarajevo within the Department of Management and Information technology. Her primary research interests lie in the Innovation management, Business Process Management and Interorganizational collaboration. She authored numerous research papers. Two years ago she has been promoted to Head of Faculty Development Center. Author can be contacted at amila.pilav-velic@efsa.unsa.ba

Nedim Suta, MA is academic staff member at Faculty of Science, Department of Biology since 2011 (got promoted to Senior Teaching Assistant in 2014) and PhD candidate in the field of Ecology/Behavior biology at the same institution. He also obtained specialization in Behavioral biology of humans and animals in 2010, which is also his primary research interest. He is also an author of numerous research papers and university publications. Author can be contacted at nedim_shuta@hotmail.com

Anes Hrnjic, MA is Teaching Assistant at University of Sarajevo within Department of Management and Organization since 2013 and PhD student in the field of Business/Management at the same institution. Previously, he obtained his Bachelor of Science degree in Business Administration in the United Sates at Stillman College and Master's degree at University of Sarajevo. Past experience include work in organizations such as European Projects Association in Brussels or largest tele operator in his native country. Author can be contacted at anes.hrnjic@efsa.unsa.ba 